\title{
Spatial and Temporal Variations of Climate on Different Flanks and Elevations in the Qinling-Daba Mountains of China from 1969 to 2018
}

\author{
Xincan Lan \\ Henan University \\ Wuyang Li \\ Henan University \\ Jiale Tang \\ Henan University \\ Abdul Shakoor \\ Henan University \\ Fang Zhao ( $\nabla$ zhaofang84@163.com ) \\ Henan University \\ Jiabin Fan \\ Henan University
}

\section{Research Article}

Keywords: Climate change, mountain range, QDM, National Meteorological Information Center, Temperature

Posted Date: November 19th, 2021

DOI: https://doi.org/10.21203/rs.3.rs-1062881/v1

License: (c) This work is licensed under a Creative Commons Attribution 4.0 International License. Read Full License 


\section{Abstract}

Climate change presents great variations on different flanks and elevations in the same mountain range. Analysis of the spatial and temporal variations of climate on different flanks and elevations in the north-south transition zone--the Qinling-Daba Mountains (QDM) are of great significance for exploring the complexity of climate geography pattern and phenology in China. This paper collected 118 weather stations data on daily temperature and precipitation during 19692018 from the National Meteorological Information Center, and then explored the temporal and spatial distribution characteristics of climate on different flanks and elevations. The results showed that: 1) On the whole, there was a significant warming trend in the four seasons in the past 50 years. Precipitation did not show significant variation at most stations with an exception to 8 weather stations having significant changes in trend in different seasons. 2) The temperature showed an increasing trend in different seasons, but its increasing rate varied greatly on different flanks. Generally speaking, climate change was greater on the northern flanks than that on the southern flanks in the four seasons in the QDM. Temperature tendency is greater in spring and winter than in summer and autumn on different flanks in the QDM. 3) The increase rate of temperature varied greatly at different elevations in different seasons. The warming rate was greater in the higher altitude regions than that of the lower altitude regions in summer, autumn and winter, while, in spring, however, it is higher in the lower altitudes than in the higher altitudes.

\section{Introduction}

The Qinling-Daba Mountains (QDM), located at the transition zone between the north and the south, and between the Tibetan Plateau and the plain in China, is considered as the natural boundary between the warm temperate zone and north subtropical zone, and an ecological corridor connecting the Tibetan Plateau and the eastern plains in China ${ }^{1,2}$. The climate of the QDM is accordingly characterized by complication and diversity on different flanks and terrains ${ }^{3-5}$. The southern flank of the Qinling Mountains, serving as the windward slope of moisture-carrying air from the southeast, sunny slope, and relatively flat slope affected by fold belts, is wet and warm, while the northern flank, as leeward, shady, and steep slope formed by fault belts, is relatively dry and cold ${ }^{1,6}$. Accordingly, climate change and its influence varied greatly from different flanks and altitudes. It has been recognized that the humidification rate, climate warming is greater on the northern flank than on the southern flank in the Qinling Mountains ${ }^{7,8}$, but vegetation NPP improvement is higher on the southern than on the northern flank in the Qinling Mountains below $2000 \mathrm{~m} 4,7$. However, most of the

previous studies mainly focus on climate change of partial regions, such as the Qinling Mountains ${ }^{3,7,9}$, Huaihe basin ${ }^{10}$, the Daba Mountains ${ }^{11}$ in the QDM. Although the QDM is an integrated geographic region connecting the warm temperate zone to the north subtropical zone, little attention is paid to climate change in the entire region ${ }^{1}$. This paper aims at revealing climate change and its complexity of different flanks and altitudes in the QDM, which contribute to the exploration of the cause of north-south regional differentiation in China. In this paper, we first collected and compiled temperature data and precipitation data at 1969-2018 from weather stations, and then carried out the ManneKendall method to analyze the heterogeneity and similarity with climate change on different flanks and altitudes in the QDM from 1969 to 2018.

\section{Materials And Method}

\section{Study area}

The QDM are located in central China, range from $30^{\circ} \mathrm{N}$ to $36^{\circ} \mathrm{N}$ and from $101^{\circ} \mathrm{E}$ to $115^{\circ} \mathrm{E}$, and span six provinces, namely, Gansu, Sichuan, Shaanxi, Chongqing, Henan, and Hubei (Fig. 1). The Qinling-Daba Mountains consisted primarily of the Qinling Mountains and the Daba Mountains separated by the Han River Valley and form a natural boundary of between the warm temperate zone and the subtropical zone. Generally speaking, the Qinling Mountains is 
roughly coincident with the $0^{\circ} \mathrm{C}$ isotherms in January, the $800 \mathrm{~mm}$ isohyet and the 2000 -hour sunshine duration contour in China ${ }^{12}$. Variation on these climate factors causes vegetation to change gradually from a deciduous broad-leaved forest zone to an evergreen broad-leaved forest zone across the QDM from north to south ${ }^{13,14}$. West Qinling, however, is dominated by cold temperate grassland because of its higher altitude and drier climate in some valleys ${ }^{15}$.

A dataset of 118 weather stations are distributed over different flanks in the QDM. Among them, 31 and 20 stations are located on the southern and northern flanks of the Qinling Mountains. In addition, 13 and 20 stations are found on the southern and northern flanks of the Daba Mountains, respectively. Thirty-four stations are present on western flank of the Qinling-Daba Mountains (Fig. 1).

\section{Weather stations}

A dataset of 118 weather stations for daily temperature and precipitation data from 1969 to 2018 in the QDM was collected from the National Meteorological Information Center (https://data.cma.cn/), and then the temperature and precipitation data were averaged by year, season and month. As shown in Fig 1邓weather stations are mainly distributed over 6 provinces including Gansu, Shaanxi, Henan, Sichuan, Hubei and Chongqing.

\section{DEM data}

In this paper, the digital elevation model (DEM) data was first downloaded from the USGS website (https://earthexplorer.usgs.gov/) by the location of different blocks of the QDM, and then spliced into a complete regional elevation data covering the whole QDM with a spatial resolution of $1000 \mathrm{~m}$. In order to analyze the association between climate change and altitude, DEM data were classified into four levels: $0 \otimes 1000 \mathrm{~m}, 1000 \otimes 2000 \mathrm{~m}, 2000 \rrbracket 3000 \mathrm{~m}$ and $3000 \varangle 4000 \mathrm{~m}$. The variation characteristics of weather stations (1969『2018) were determined in different classification segments and the relationship between climate change and elevation was explored in the QDM.

\section{Exposure data}

To decipher the association between climate change and different flanks in the QDM, we divided QDM into five parts. The southern and northern flanks of the Qinling Mountains, and the southern and northern flanks of the Daba Mountains, and the west Qinling-Daba Mountains. We classified and divided the QDM parts on the basis of positions of the main ridge lines and major rivers (Jialing River and Han River) in (Fig.1). Temperature and precipitation change rates were calculated by statistic analysis in the five regions to explore the similarity and dissimilarity of climate change on different flanks in the north-south transitional zone of China.

\section{Method}

The widely-used Manne-Kendall method is an effective test to detect the long-term change in time series ${ }^{16}$. The detailed treated method is described in Xu et al. ${ }^{17}$. In this study, the Manne-Kendall method was applied to detect the long-term trend of temperature and precipitation changes on different flanks and elevations based on these 118 meteorological data in the QDM.

\section{Results}

\section{Temperature changes on different flanks in the QDM from 1969 to 2018}

The Mann-Kendall test revealed $91.53 \%$ (108 stations) of stations presenting a significant increasing trend in spring temperature (Fig. 2), while 51.69\% (61 stations), 77.12\% (91 stations) and $86.44 \%$ (102 stations) of weather stations showed substantial trend in summer, autumn and winter temperatures, respectively. The greater proportion of 
stations showed significant temperature trends on the west Qinling-Daba Mountains than on the other flanks in different seasons. In this case, $97.06 \%, 88.24 \%, 94.12 \%$ and $97.06 \%$ of stations were found to have a notable warming trend on the West Qinling Mountains in spring, summer, autumn, and winter, respectively, while stations are less than $89.29 \%, 35.71 \%, 69.05 \%, 80.95 \%$ on the other flanks. The northern flanks have had more proportion of weather stations showing significant warming trend in different seasons as compared to the southern flank in the Qinling Mountains. For instance, $95 \%, 40 \%, 75 \%$ and $95 \%$ of stations significant warming trend in the former in spring, summer, autumn, and winter, respectively, while $93.55 \%, 35.48 \%, 64.52 \%$ and $87.10 \%$ of stations showing significant warming trend in the latter in the four seasons, respectively. The southern flank in Daba Mountains, with 7.69\% stations depicted a significant negative trend in summer, autumn and winter.

The trend analysis for the mean temperature of different seasons revealed that there was a significant warming trend on different flanks in the QDM from 1969 to 2018 (Fig.3, Table1). However, the increasing rate varied greatly from different seasons and flanks. The temperature increasing rate was greater on the northern flank of the Qinling Mountains and the Daba Mountains as compared to the southern flanks in the four seasons (Fig. 3). Among them, the temperature tendency is greater in spring and winter than in summer and autumn on different flanks in the QDM. Climate warming was least in summer with temperature increasing rate as low as $0.123^{\circ} \mathrm{C} / 10 \mathrm{a}, 0.074^{\circ} \mathrm{C} / 10 \mathrm{a}$, $0.085^{\circ} \mathrm{C} / 10 \mathrm{a}, 0.056^{\circ} \mathrm{C} / 10 \mathrm{a}$, and $0.285^{\circ} \mathrm{C} / 10 \mathrm{a}$, respectively, on the northern flank of Qinling Mountains, the southern flank of Qinling Mountains, the northern flank of Daba Mountains, the southern flank of Daba Mountains, and the West Qinling-Daba Mountains.

Table 1. Seasonal temperature trends $\left({ }^{\circ} \mathrm{C} / 10 \mathrm{a}\right)$ on different flanks in the QDM during 1969ه2018. Notes: ** indicates that the climate trends are significant at the level of 0.05 and 0.01 , respectively.

\begin{tabular}{|c|c|c|c|c|}
\hline $\begin{array}{l}\text { Different } \\
\text { flanks }\end{array}$ & $\begin{array}{l}\text { Spring } \\
\text { Temperature } \\
\left({ }^{\circ} \mathrm{C} / 10 \mathrm{a}\right)\end{array}$ & $\begin{array}{l}\text { Summer } \\
\text { Temperature } \\
\left({ }^{\circ} \mathrm{C} / 10 \mathrm{a}\right)\end{array}$ & $\begin{array}{l}\text { Autumn } \\
\text { Temperature } \\
\left({ }^{\circ} \mathrm{C} / 10 \mathrm{a}\right)\end{array}$ & $\begin{array}{l}\text { Winter } \\
\text { Temperature } \\
\left({ }^{\circ} \mathrm{C} / 10 \mathrm{a}\right)\end{array}$ \\
\hline $\begin{array}{l}\text { Southern flank of } \\
\text { Qinling Mountains }\end{array}$ & $0.342^{\star \star}$ & $0.074 * *$ & $0.181^{* *}$ & $0.267 * \star$ \\
\hline $\begin{array}{l}\text { Northern flank of } \\
\text { Qinling Mountains }\end{array}$ & $0.479 * \star$ & $0.123^{\star *}$ & $0.205^{\star \star}$ & $0.374 * \star$ \\
\hline $\begin{array}{l}\text { Southern flank of } \\
\text { Daba Mountains }\end{array}$ & $0.224 \star \star$ & $0.056 * \star$ & $0.112^{\star \star}$ & $0.234 * \star$ \\
\hline $\begin{array}{l}\text { Northern flank of } \\
\text { Daba Mountains }\end{array}$ & $0.338 * \star$ & $0.085^{\star \star}$ & $0.194 * \star$ & 0.274 ** \\
\hline West Qinling-Daba Mountains & $0.350 * *$ & $0.285^{\star *}$ & $0.308 * *$ & $0.362^{\star *}$ \\
\hline
\end{tabular}

\section{Temperature changes into different elevations in the QDM from 1969 to 2018}

The significance statistics of trends in mean temperature showed that stations detected significant increasing trend varies greatly varied on different seasons and altitudes in the QDM (Fig.4). In the QDM, 89.77\% (79 stations), 35.23\% (31 stations), 69.32\% (61 stations), and $81.82 \%$ (72 stations) of stations were detected to have a significant warming trend at $0 \otimes 1000 \mathrm{~m}$ altitude in spring, summer, autumn, and winter, while the proportion of stations with a significant increasing trend was greater than $98.68 \%, 92.50 \%$, and $100 \%$ at other elevations $(1000 \otimes 2000 \mathrm{~m}, 2000 \otimes 3000 \mathrm{~m})$. In 
different seasons, it was discovered that high altitude areas have a higher proportion of warming area than low altitude areas.

The temperature trend analysis for different seasons revealed that there was a significant warming trend at different elevations in the QDM from 1969 to 2018. (Fig. 5, Table 2). However, the rate of increase in mean temperature varied greatly depending on the season and elevation. In higher elevation, we detected an increasing rate in the mean temperature of summer, autumn, and winter (Fig. 5, Table 2). At elevations of $3000 \otimes 4000 \mathrm{~m}$, the increasing rate could reach $0.440^{\circ} \mathrm{C} / 10 \mathrm{a}, 0.39^{\circ} \mathrm{C} / 10 \mathrm{a}$, and $0.456^{\circ} \mathrm{C} / 10 \mathrm{a}$, respectively, while at $0 \otimes 1000 \mathrm{~m}$, it was $0.205^{\circ} \mathrm{C} / 10 \mathrm{a}, 0.218^{\circ} \mathrm{C} / 10 \mathrm{a}$, and $0.303^{\circ} \mathrm{C} / 10 \mathrm{a}$, respectively. The increasing rate in spring is higher in the lower altitude areas (at $0 \otimes 1000 \mathrm{~m}$ and $1000 \otimes$ $2000 \mathrm{~m}$ ) than in the higher altitude areas (at 2000ه3000m and $3000 \varangle 4000 \mathrm{~m}$ ).

Table 2. Seasonal mean temperature increasing rates $\left({ }^{\circ} \mathrm{C} / 10 \mathrm{a}\right)$ at different elevations in the QDM during $1969 \otimes 2018$. Notes: * and ** indicate that the climate trends are significant at the level of 0.05 and 0.01 , respectively, by the MannKendall test for the long-term trend.

\begin{tabular}{|c|c|c|c|c|}
\hline $\begin{array}{l}\text { Elevation } \\
\text { classification }(m)\end{array}$ & $\begin{array}{l}\text { Spring } \\
\text { Temperature( }\left({ }^{\circ} \mathrm{C} / 10 \mathrm{a}\right)\end{array}$ & $\begin{array}{l}\text { Summer } \\
\text { Temperature }\left({ }^{\circ} \mathrm{C} / 10 \mathrm{a}\right)\end{array}$ & $\begin{array}{l}\text { Autumn } \\
\text { Temperature }\left({ }^{\circ} \mathrm{C} / 10 \mathrm{a}\right)\end{array}$ & $\begin{array}{l}\text { Winter } \\
\text { Temperature }\left({ }^{\circ} \mathrm{C} / 10 \mathrm{a}\right)\end{array}$ \\
\hline $0 \square 1000$ & $0.369 * \star$ & $0.205^{\star \star}$ & $0.218^{\star \star}$ & $0.303^{\star \star}$ \\
\hline $1000 \square 2000$ & $0.405^{\star \star}$ & $0.281^{\star \star}$ & $0.308^{\star}$ & $0.384^{\star \star}$ \\
\hline $2000 \square 3000$ & $0.351^{\star \star}$ & $0.359 * \star$ & $0.339 * *$ & $0.405^{\star \star}$ \\
\hline $3000 \square 4000$ & $0.317^{\star \star *}$ & 0.440 ** & $0.390 * \star$ & $0.456^{* *}$ \\
\hline
\end{tabular}

\section{Precipitation changes into different flanks and elevations in the QDM from 1969 to 2018}

The Mann-Kendall test did not show a significant trend in precipitation. However, some stations exhibited notable trends in spring, summer, and winter precipitations (Fig. 6). Weather stations were distributed at different elevations. For instance, Mount Hua station was present at $2000 \otimes 3000 \mathrm{~m}$ on the northern flank of the Qinling Mountains. Shiquan station location was at $0 \otimes 1000 \mathrm{~m}$ on the southern flank of the Qinling Mountains. Taibai station at $1000 \otimes 2000 \mathrm{~m}$ on the southern flank of Qinling Mountains, Zigui stations at 0区1000m on the southern flank of Daba Mountains, Beichuan station at 0囚1000m, Diebu, Songpan and Hezuo stations at 2000囚3000m on the west Qinling-Daba Mountains.

As shown in Fig.7 and Table 3, there were two weather stations, Zigui and Shiquan, that showed significant increasing trends in precipitation in summer, and 1 weather station (Diebu) that showed significant decrease trends, with change rates as high as $47.36 \mathrm{~mm} / 10 \mathrm{a}, 22.91 \mathrm{~mm} / 10 \mathrm{a}$, and $\nabla 19.43 \mathrm{~mm} / 10 \mathrm{a}$, respectively, which were higher than other stations in other seasons. In contrast, four weather stations (Zigui, Beichuan, Taibai, and Hezuo) indicated increasing and decreasing changes in precipitation in winter. It is important to note that Mount Hua weather station recorded a significant decrease in precipitation in spring and autumn, with rates of $\nabla 14.60 \mathrm{~mm} / 10 \mathrm{a}$ and $\nabla 11.50 \mathrm{~mm} / 10 \mathrm{a}$, respectively. Only in spring, the Songpan weather station depicted an increasing trend, i.e., $7.63 \mathrm{~mm} / 10 \mathrm{a}$ in precipitation.

Table 3. Seasonal mean precipitation change rates $(\mathrm{mm} / 10 \mathrm{a})$ at the weather station with significant trend in different seasons in the QDM during1969ه2018. Notes: * and ** indicate that the climate trends are significant at the level of 0.05 and 0.01 levels, respectively, by the Mann-Kendall test for the long-term trend. 


\begin{tabular}{|c|c|c|c|c|c|c|c|}
\hline $\begin{array}{l}\text { Stations } \\
\text { Name }\end{array}$ & $\begin{array}{l}\text { Latitude } \\
\left(\mathrm{N}^{\circ}\right)\end{array}$ & $\begin{array}{l}\text { Longitude } \\
\left(E^{\circ}\right)\end{array}$ & $\begin{array}{l}\text { Altitude } \\
\text { (m) }\end{array}$ & $\begin{array}{l}\text { Spring } \\
\text { Precipitation } \\
(\mathrm{mm} / 10 \mathrm{a})\end{array}$ & $\begin{array}{l}\text { Summer } \\
\text { Precipitation } \\
(\mathrm{mm} / 10 \mathrm{a})\end{array}$ & $\begin{array}{l}\text { Autumn } \\
\text { Precipitation } \\
(\mathrm{mm} / 10 \mathrm{a})\end{array}$ & $\begin{array}{l}\text { Winter } \\
\text { Precipitation } \\
\text { (mm/10a) }\end{array}$ \\
\hline Zigui & 30.83 & 110.97 & 295.50 & $\square$ & $47.36^{\star \star}$ & प & $6.33^{\star}$ \\
\hline Shiquan & 33.05 & 108.27 & 484.90 & प & $22.91 *$ & प & 口 \\
\hline Beichuan & 31.63 & 104.45 & 597.20 & $\square$ & प & प & $1.65^{\star}$ \\
\hline Taibai & 34.03 & 107.32 & 1543.60 & प & a & 口 & $2.13^{\star \star}$ \\
\hline $\begin{array}{l}\text { Mount } \\
\text { Hua }\end{array}$ & 34.48 & 110.08 & 2064.90 & $\nabla 14.60 * *$ & & $\bigotimes 11.5^{\star}$ & 口 \\
\hline Diebu & 34.07 & 103.23 & 2374.20 & प & $\otimes 19.43^{*}$ & प & प \\
\hline Songpan & 32.67 & 103.60 & 2881.30 & $7.63^{\star}$ & 口 & 口 & 口 \\
\hline Hezuo & 35.00 & 102.90 & 2910.00 & 口 & [ & [ & $1.19^{*}$ \\
\hline
\end{tabular}

\section{Discussion}

Our analysis confirmed that the temperature had an increasing trend in the QDM in the last 50 years, but the climate increasing rate presented great variations on different flanks and elevations. On the whole, climate changing rate was greater on the northern flanks than the southern flanks in the four seasons in the QDM. For example, the climatechanging rate can be as high as $0.374^{\circ} \mathrm{C} / 10 \mathrm{a}$ and $0.456^{\circ} \mathrm{C} / 10 \mathrm{a}$ on the northern flank of Qinling Mountains, and at $3000-4000 \mathrm{~m}$ in the QDM, it is as low as $0.267^{\circ} \mathrm{C} / 10 \mathrm{a}$ and $0.303^{\circ} \mathrm{C} / 10 \mathrm{a}$, respectively, on the southern flank of Qinling Mountains and at $0 \bigotimes 1000 \mathrm{~m}$ in the QDM in the last 50 years. This result was also identified by Xiaodong Liu and Yibin Yao 's research on the Qinghai-Tibet Plateau ${ }^{18,19}$. Similarly, Min Xu et al. ${ }^{20}, \mathrm{M}$. BENISTON et al ${ }^{21}$. and Imtiaz Rangwala et al. also found that the climate warming rate was higher in high-elevation areas than in low-elevation areas, respectively, in Tianshan Mountains, the Swiss Alps and the Colorado Rockies. The possible reason is that temperature change is more sensitive to driving factors such as snow/ice coverage ${ }^{22}$, cloud $^{18,23}$, water vapor ${ }^{24,25}$ and soil moisture ${ }^{26}$ in high altitude areas and on northern flanks with relatively higher latitudes.

Current findings highlighted the variation in climate warming in different seasons. Increasing temperature rate was recorded in higher altitudes in summer, autumn, and winter. On the contrary, it was higher in the lower altitudes than higher altitudes. In addition, the temperature tendency is greater in spring and winter than in summer and autumn on different flanks in the QDM. Present findings indicated the climate warming was more pronounced in spring and winter. These results coincide with previous results by Gao Xiang and Zhu Yi et al. on climate change in the QDM and QinghaiTibet Plateau ${ }^{27}$. Plausible explanations for these results are vegetation $D N V l^{28}$, latent heat generated by local precipitation ${ }^{29}$, and temperature inversion due to topography ${ }^{30}$, Anthropogenic factors coupled with surface albedo changes due to land use explain the temperature variation in different seasons of the mountain ${ }^{2,31}$ and the combined effect of these factors caused the diversity of temperature changes among different seasons in the interior of the mountain system with complex topography.

The precipitation did not change significantly in most areas from 1969-2018, except for 8 weather stations. Weather stations showed a consistent tendency of increasing precipitation in winter. This means that the climate becomes wetter in winter, which helps to alleviate winter droughts in the QDM, especially, the West Qinling-Daba Mountains. Our 
results are in line with the research results of Gou Xiaoxia on the northern slope of Tianshan Mountains ${ }^{32}$ and Gao Xiang on the QDM ${ }^{8}$. The wetter winter may play an important role in the changes of vegetation, phenology ${ }^{33}, \mathrm{NPP}^{34}$, $\mathrm{NDVI}^{35}$, which should be studied further in the future.

\section{Conclusion}

We used climate statistical analysis methods to analyze the spatiotemporal trends of temperature and precipitation during 1969-2018on different flanks and elevations in the QDM. The following conclusions were obtained:

(1) On the whole, there was an obvious warming trend in different seasons in the past 50 years in the QDM, but seasonal temperature increasing rate varied greatly on different flanks and elevations. The precipitation did not change significantly in most areas from 1969-2018, except for 8 weather stations showing significant precipitation changes to a certain degree in different seasons in the QDM.

(2) Seasonal climate warming presented great variations on different flanks. Generally speaking, climate change was greater on the northern flanks than that on the southern flanks in the four seasons in the QDM. Among them, the temperature tendency is greater in spring and winter than in summer and autumn on different flanks in the QDM.

(3) There was an increasing trend of seasonal temperatures at different elevations in different seasons in the QDM. As the elevation increases, the increasing rate of mean temperature showed a tendency of rising in summer, autumn and winter, while, in spring, however, it is higher in the lower altitudes than in the higher altitudes.

\section{Declarations}

\section{Acknowledgements}

This research was funded by the National Natural Science Foundation of China (41601091) and Integrated Scientific Investigation of the North-South Transitional Zone of China (2017FY100900). The funders had no role in study design, data collection and analysis, decision to publish or preparation of the manuscript.

\section{Author contributions}

Conceptualization, Zhao, F. ; methodology, Lan, X. ; data curation and visualization, Li, W.; writing-original draft preparation, Zhao, F. and Lan, X. writing-review and editing, Tang, J. and Shakoor, A. All authors have read and agreed to the published version of the manuscript.

\section{Competing interests}

The authors declare no competing interests.

\section{References}

1. Zhao, F., Liu, J. J., Zhu, W. B., Zhang, B. P., Zhu, L. Q. Spatial variation of altitudinal belts as dividing index between warm temperate and subtropical zones in the Qinling-Daba Mountains. Journal of Geographical Sciences 30, 642656 (2020). https://doi.org/10.1007/s11442-020-1747-2.

2. Zhao, F., Lan, X. C., Li, W. Y., Zhu, W. B., Li, T. Q. Influence of Land Use Change on the Surface Albedo and Climate Change in the Qinling-Daba Mountains. Sustainability 13, (2021). https://doi.org/10.3390/su131810153. 
3. Zhang, Y., Bai, H. Y., Su, K., Huang, X. Y., Meng, Q., Guo, S. Z. Spatial variation of extreme temperature change on southern and northern slopes of Shaanxi section in Qinling Mountains during 1960-2013 (in Chinese). Acta Geographica Sinica 73, 1296-1308 (2018). https://doi.org/10.11821/dlxb201807009.

4. Zhao, F., Zhang, J. Y., Liu, S. Y., Wang, Z. Y., Wang, L. H., Gu, H. T., Li, W. L. Assessing the dividing line between warm temperate and subtropical zones based on the zonality discussion on multi-dimensional response of Net Primary Productivity to climate change in the Qinling-Daba Mountains (in Chinese). Acta Ecologica Sinica 41, 57-68 (2021). https://doi.org/10.5846/stxb201911252547.

5. Zhang, W. J., Zhang, B. P., Zhu, W. B., Tang, X. L., Li, F. J., Liu, X. S., Yu, Q. Comprehensive assessment of MODISderived near-surface air temperature using wide elevation-spanned measurements in China. Science of The Total Environment 800, 149535 (2021). https://doi.org/10.1016/j.scitotenv.2021.149535.

6. Zhang, B., Xu, J., Wu, H., Xiao, F., Zhu, Y. Digital integration and pattern analysis of mountain altitudinal belts in China. Journal of Mountain Science 24, 144-149 (2006). https://doi.org/10.1109/TPSD.2006.5507455.

7. Qi, G. Z., Bai, H. Y., Zhao, T., Meng, Q., Zhang, S. H. Sensitivity and areal differentiation of vegetation responses to hydrothermal dynamics on the northern and southern slopes of the Qinling Mountains in Shaanxi province. Journal of Geographical Sciences 31, 785-801 (2021). https://doi.org/10.11821/dlxb202101004.

8. Gao, X., Bai, H. Y., Zhang, S. L., He, Y. N. Climatic change tendency in Qinling Mountains from 1959 to 2009. Bulletin of Soil Water Conservation 32, 207-211 (2012). https://doi.org/10.13961/j.cnki.stbctb.2012.01.008.

9. Guo, S. Z., Bai, H. Y., Meng, Q., Zhao, T., Huang, X. Y., Qi, G. Z. Landscape pattern changes of woodland and grassland and its driving forces in Qinling Mountains. Acta Ecologica Sinica 40, (2020). https://doi.org/10.5846/stxb201811072418.

10. Li, S. S., Yang, S. N., Liu, X. F. Spatiotemporal variability of extreme precipitation in north and south of the QinlingHuaihe region and influencing factors during 1960-2013. Prog. Geogr 34, 354-363 (2015). https://doi.org/10.11820/dlkxjz.2015.03.010.

11. Li, R. K., Li, Y. B. Spatio-temporal change of soil erosion intensity on the foothills of the Daba Mountains from 1988 to 2020-a case study from the hinterland of the Three Gorges Reservoir area, China. Arabian Journal of Geosciences 14, 1-17 (2021). https://doi.org/10.1007/s12517-021-07921-7.

12. Kang, M. Y., Zhu, Y. Discussion and analysis on the geo-ecological boundary in Qinling Range(in Chinese). Acta Ecologica Sinica 27, 2774-2784 (2007).

13. Chen, M. R. Regionalization of vertical temperature zones in QinLing Mountain range. Geographical Research $\mathbf{3}$, (1992). https://doi.org/10.11821/yj1992030006.

14. Lei, M. D., Vegetation of Shaanxi(in Chinese). 1999, Beijing: Science Press.

15. Zhao, F., Zhang, B. P., Zhu, L. Q., Yao, Y. H., Cui, Y. P., Liu, J. J. Spectra structures of altitudinal belts and their significance for determining the boundary between warm temperate and subtropical zones in the Qinling-Daba Mountains(in Chinese) Acta Geographica Sinica 74, 889-901 (2019). https://doi.org/10.11821/dlxb201905004.

16. Burn, D. H., Elnur, M. A. H. Detection of hydrologic trends and variability. Journal of hydrology 255, 107-122 (2002). https://doi.org/10.1016/S0022-1694(01)00514-5.

17. Xu, C., Li, J., Zhao, J., Gao, S., Chen, Y. Climate variations in northern Xinjiang of China over the past 50 years under global warming. Quaternary Internationa/358, 83-92 (2015). http://dx.doi.org/10.1016/j.quaint.2014.10.025.

18. Liu, X. D., Cheng, Z. G., Yan, L. B., Yin, Z. Y. Elevation dependency of recent and future minimum surface air temperature trends in the Tibetan Plateau and its surroundings. Global Planetary Change 68, 164 (2009). https://doi.org/10.1016/j.gloplacha.2009.03.017.

19. Yao, Y. B., Lei, X. X., Zhang, L., Zhang, B., Peng, H., Zhang, J. H. Analysis of precipitable water vapor and surface temperature variation over Qinghai-Tibetan Plateau from 1979 to 2014. Chinese Science Bulletin 61, 1462-1477 
(2016). https://doi.org/10.1360/N972015-00850.

20. Xu, M., Kang, S. C., Wu, H., Yuan, X. Detection of spatio-temporal variability of air temperature and precipitation based on long-term meteorological station observations over Tianshan Mountains, Central Asia. Atmospheric research 203, 141-163 (2018). https://doi.org/10.1016/j.atmosres.2017.12.007.

21. Beniston, M., Diaz, H., Bradley, R. Climatic change at high elevation sites: an overview. Climatic Change 36, 233-251 (1997). https://doi.org/10.1023/A:1005380714349.

22. Rangwala, I., Barsugli, J., Cozzetto, K., Neff, J., Prairie, J. Mid-21st century projections in temperature extremes in the southern Colorado Rocky Mountains from regional climate models. Climate dynamics 39, 1823-1840 (2012). https://doi.org/10.1007/s00382-011-1282-z.

23. Beniston, M., Rebetez, M. Regional behavior of minimum temperatures in Switzerland for the period 1979-1993. Theoretical applied climatology 53, 231-243 (1996). https://doi.org/0.1007/BF00871739.

24. Rangwala, I., Miller, J. R., Xu, M. Warming in the Tibetan Plateau: possible influences of the changes in surface water vapor. Geophysical research letters 36, (2009). https://doi.org/10.1029/2009GL037245.

25. Rangwala, I., Miller, J. R., Russell, G. L., Xu, M. Using a global climate model to evaluate the influences of water vapor, snow cover and atmospheric aerosol on warming in the Tibetan Plateau during the twenty-first century. Climate Dynamics 34, 859-872 (2010). https://doi.org/10.1007/s00382-009-0564-1.

26. Rangwala, I., Miller, J. R. Climate change in mountains: a review of elevation-dependent warming and its possible causes. Climatic change 114, 527-547 (2012). https://doi.org/10.1007/s10584-012-0419-3.

27. Yi, Z., Fan, G. Z., Wei, H., Wang, Q. R. Analysis of the temporal and spatial variation in land surface temperature over the Qinghai-Tibet Plateau from 1981 to 2015. Journal of Southwest University 40, 127-140 (2018).

https://doi.org/10.13718/j.cnki.xdzk.2018.11.018.

28. Cui, X. L., Bai, H. Y., Wang, T. Difference in NDVI with altitudinal gradient and temperature in Qinling area. Resour Sci 35, 618-626 (2013).

29. Schneider, T., O'Gorman, P. A., Levine, X. J. Water vapor and the dynamics of climate changes. Reviews of Geophysics 48, (2010). https://doi.org/10.1029/2009RG000302.

30. Ding, R. H., Xu, Y. W., Ding, X. Precursor Effect of Terrain Inversion on Weather Changes Changes in Jiuhua Mountain(in Chinese). Meteorological Science And Technology 41, 1080-1085 (2013).

31. DeFries, R. S., Bounoua, L., Collatz, G. J. Human modification of the landscape and surface climate in the next fifty years. Global Change Biology 8, 438-458 (2002). https://doi.org/10.1046/j.1365-2486.2002.00483.x.

32. Gou, X. X., Yang, Y. H., Ye, M., Zhang, T. G., Wang, L. A study of climate change regularity of different elevations of the northern slope of Tianshan Mountain. Journal of Yunnan University-Natural Sciences Edition 41, 333-342 (2019). https://doi.org/10.7540/j.ynu.20180110.

33. Penuelas, J., Filella, I., Zhang, X. Y., Llorens, L., Ogaya, R., Lloret, F., Comas, P., Estiarte, M., Terradas, J. Complex spatiotemporal phenological shifts as a response to rainfall changes. New Phytologist 161, 837-846 (2004). https://doi.org/10.1111/j.1469-8137.2004.01003.x.

34. Wu, G., Wang, Y. X., Yu, D. Y., Pan, Y. Z., Zhang, L., Shao, H. B. The impact of atmosphere circular system on coupling features of spring net primary productivity with precipitation in East Asia. Pakistan journal of biological sciences : PJBS 10, 2800-8 (2007). https://doi.org/10.3923/pjbs.2007.2800.2808

35. Wang, J., Rich, P. M., Price, K. P. Temporal responses of NDVI to precipitation and temperature in the central Great Plains, USA. International Journal of Remote Sensing 24, 2345-2364 (2003).

https://doi.org/10.1080/01431160210154812.

\section{Figures}

Page $9 / 16$ 


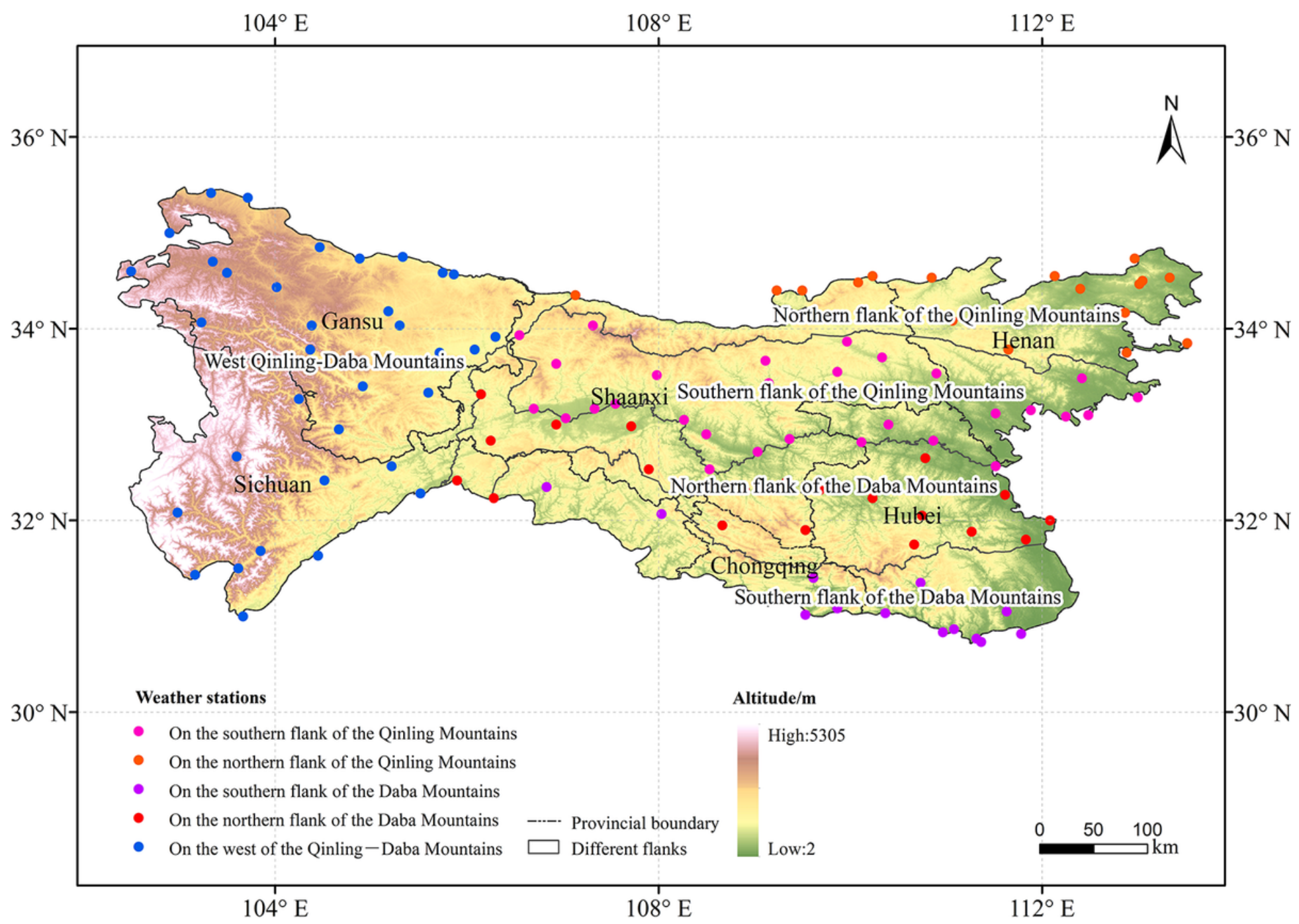

\section{Figure 1}

The study area and the spatial distribution of weather station in the QDM. Pink dots represent weather stations on the southern flank of the Qinling Mountains (31); orange dots represent weather stations on the northern flank of the Qinling Mountains (20); purple dots represent weather stations on the southern flank of the Daba Mountains (13); red dots represent weather stations on the northern flank of the Daba Mountains (20) and blue dots represent weather stations on the west of the Qinling-Daba Mountains (34). 

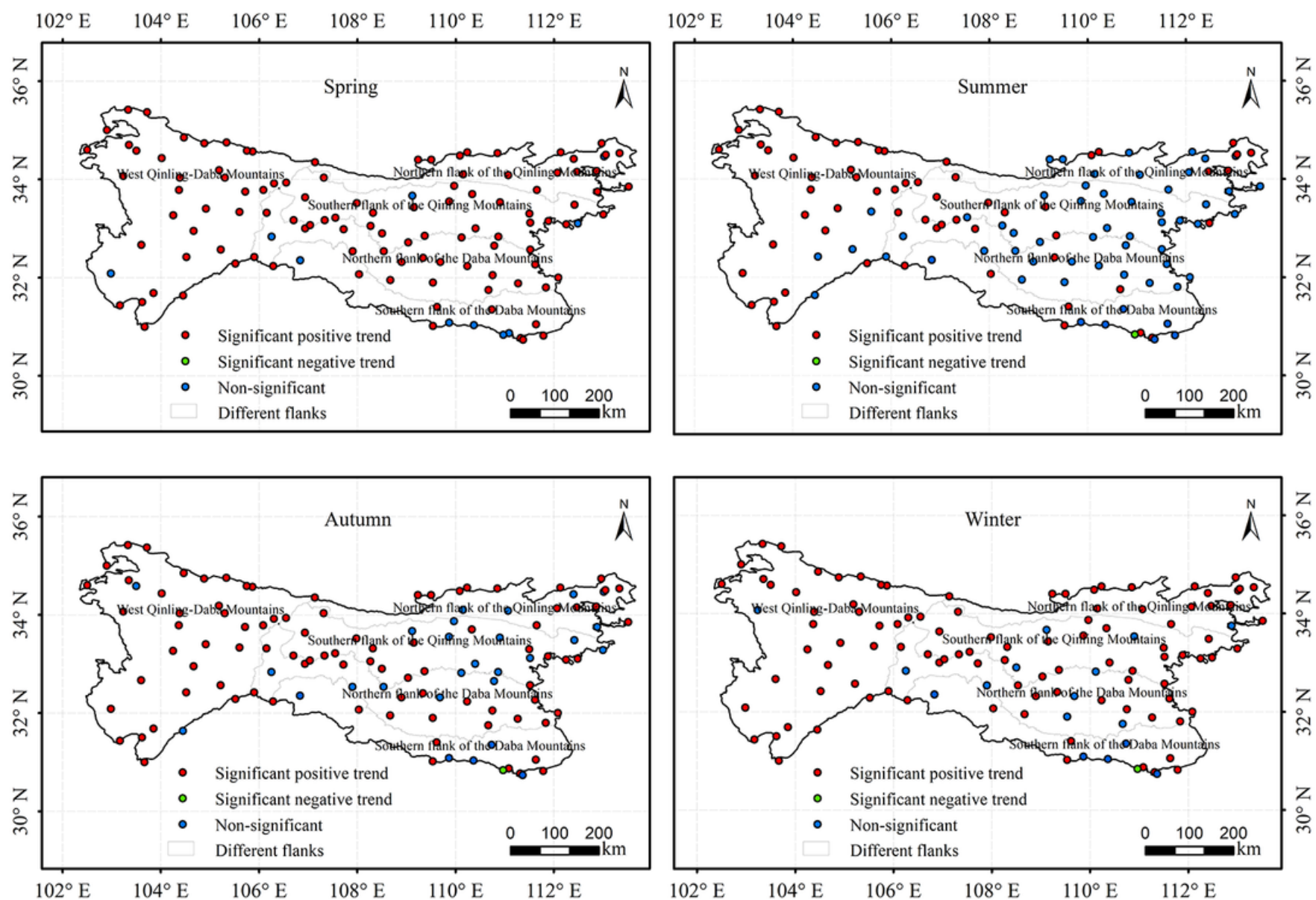

Figure 2

Significance analysis of mean temperature based on Mann-Kendall test at the $5 \%$ significance level at different weather stations in the QDM during 1969ه2018 



Figure 3

Variation on mean temperature on the southern flank of Qinling Mountains(a), the northern flank of Qinling Mountains(b), the southern flank of Daba Mountains(c), the northern flank of Daba Mountains(d) and the west QinlingDaba Mountains(e): spring(a1,b1,c1,d1), summer(a2,b2,c2,d2), autumn (a3,b3,c3,d3) and winter (a4,b4,c4,d4) 

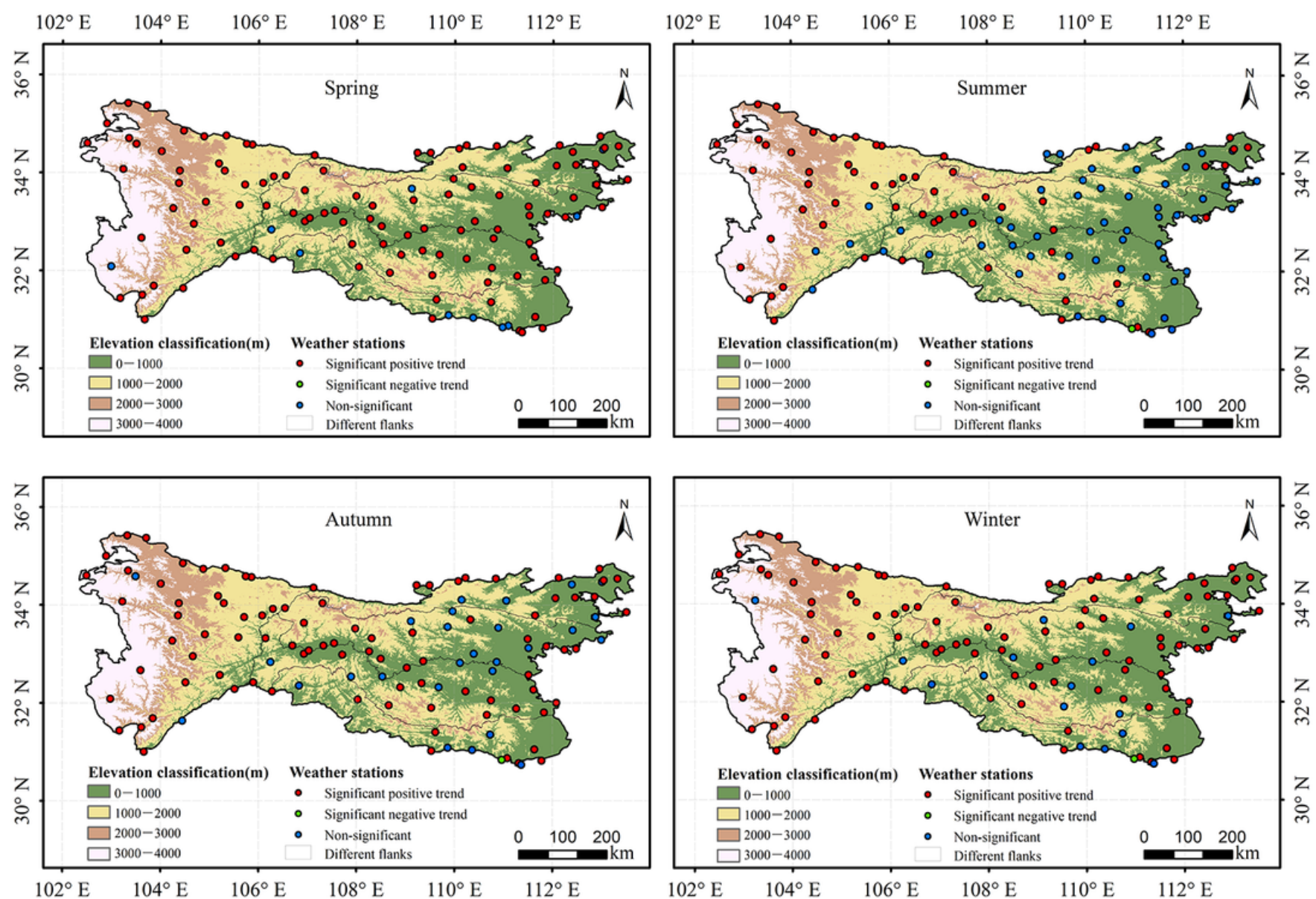

$102^{\circ} \mathrm{E} \quad 104^{\circ} \mathrm{E} \quad 106^{\circ} \mathrm{E} \quad 108^{\circ} \mathrm{E} \quad 110^{\circ} \mathrm{E} \quad 112^{\circ} \mathrm{E}$

$102^{\circ} \mathrm{E} \quad 104^{\circ} \mathrm{E} \quad 106^{\circ} \mathrm{E} \quad 108^{\circ} \mathrm{E} \quad 110^{\circ} \mathrm{E} \quad 112^{\circ} \mathrm{E}$

\section{Figure 4}

Significance analysis of mean temperature for different weather stations based on Mann-Kendall tests for the $5 \%$ significance level in different elevations and seasons in the QDM during 1969『2018 


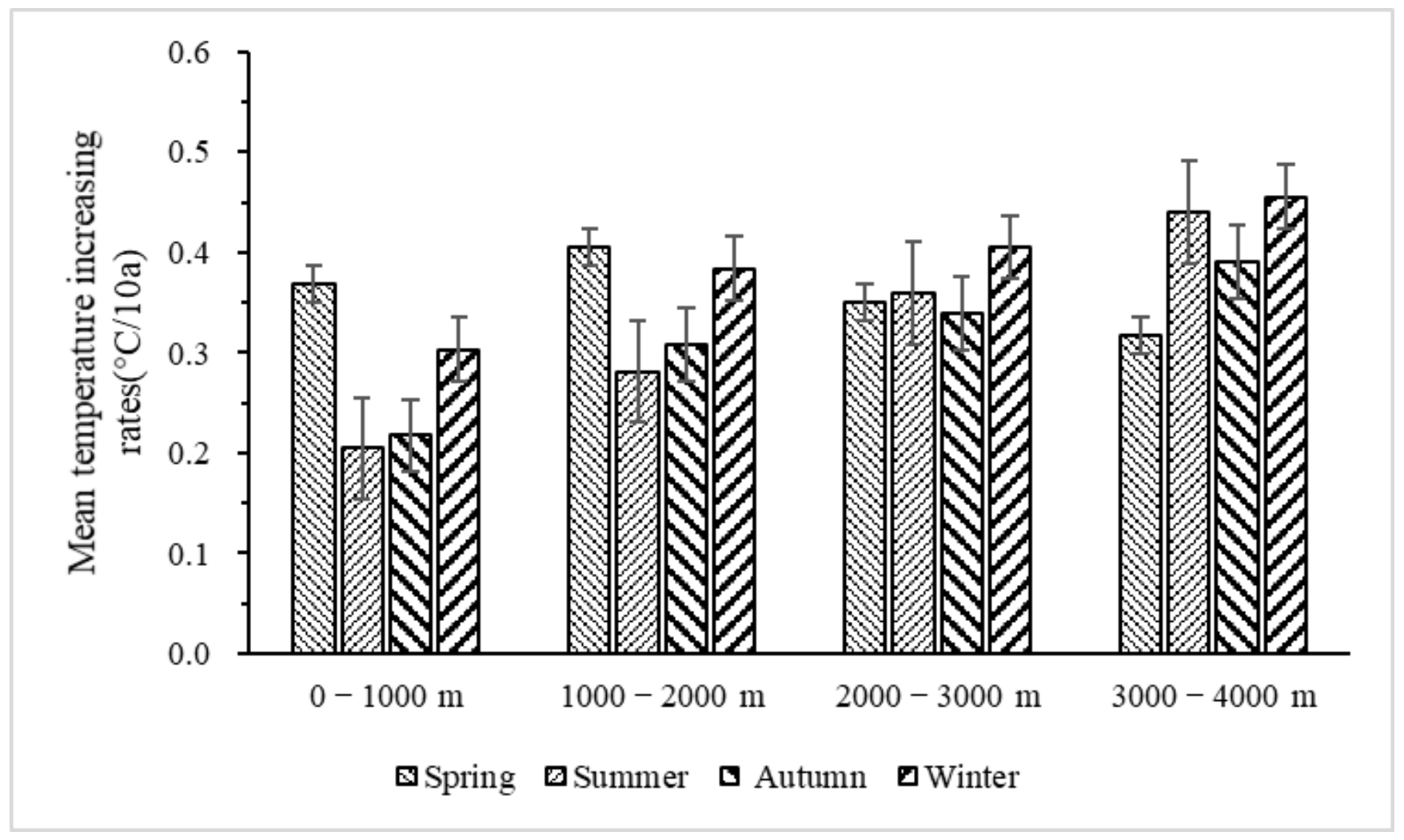

Figure 5

Seasonal temperature increasing rates of different elevations in the QDM during $1969 \rrbracket 2018$ 

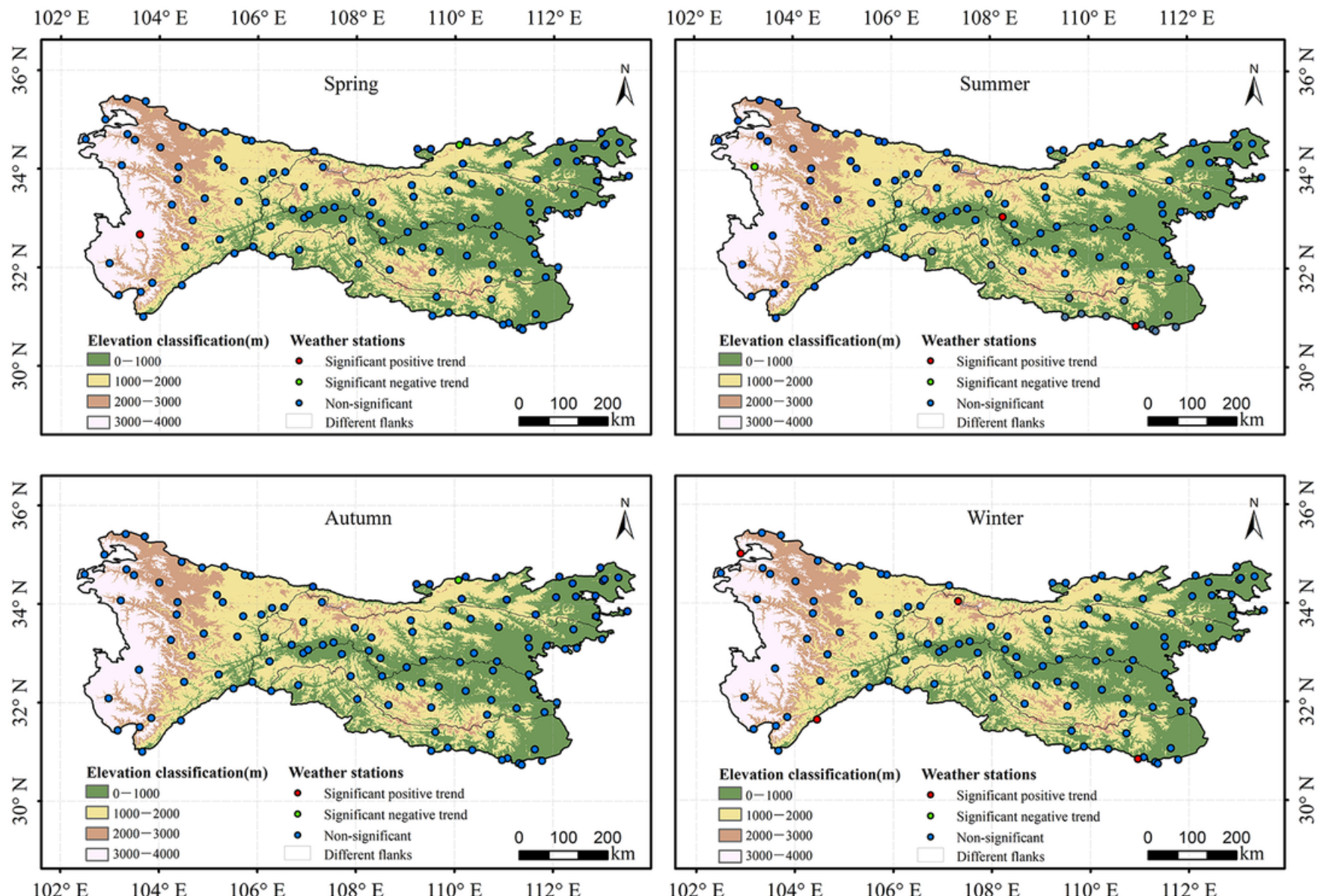

$102^{\circ} \mathrm{E} \quad 104^{\circ} \mathrm{E} \quad 106^{\circ} \mathrm{E} \quad 108^{\circ} \mathrm{E} \quad 110^{\circ} \mathrm{E} \quad 112^{\circ} \mathrm{E}$

$102^{\circ} \mathrm{E} \quad 104^{\circ} \mathrm{E} \quad 106^{\circ} \mathrm{E} \quad 108^{\circ} \mathrm{E} \quad 110^{\circ} \mathrm{E} \quad 112^{\circ} \mathrm{E}$

\section{Figure 6}

Significance analysis of precipitation changes of different weather stations based on Mann-Kendall tests for the $5 \%$ significance level on different elevations, flanks and seasons in the QDM during 1969ه2018 

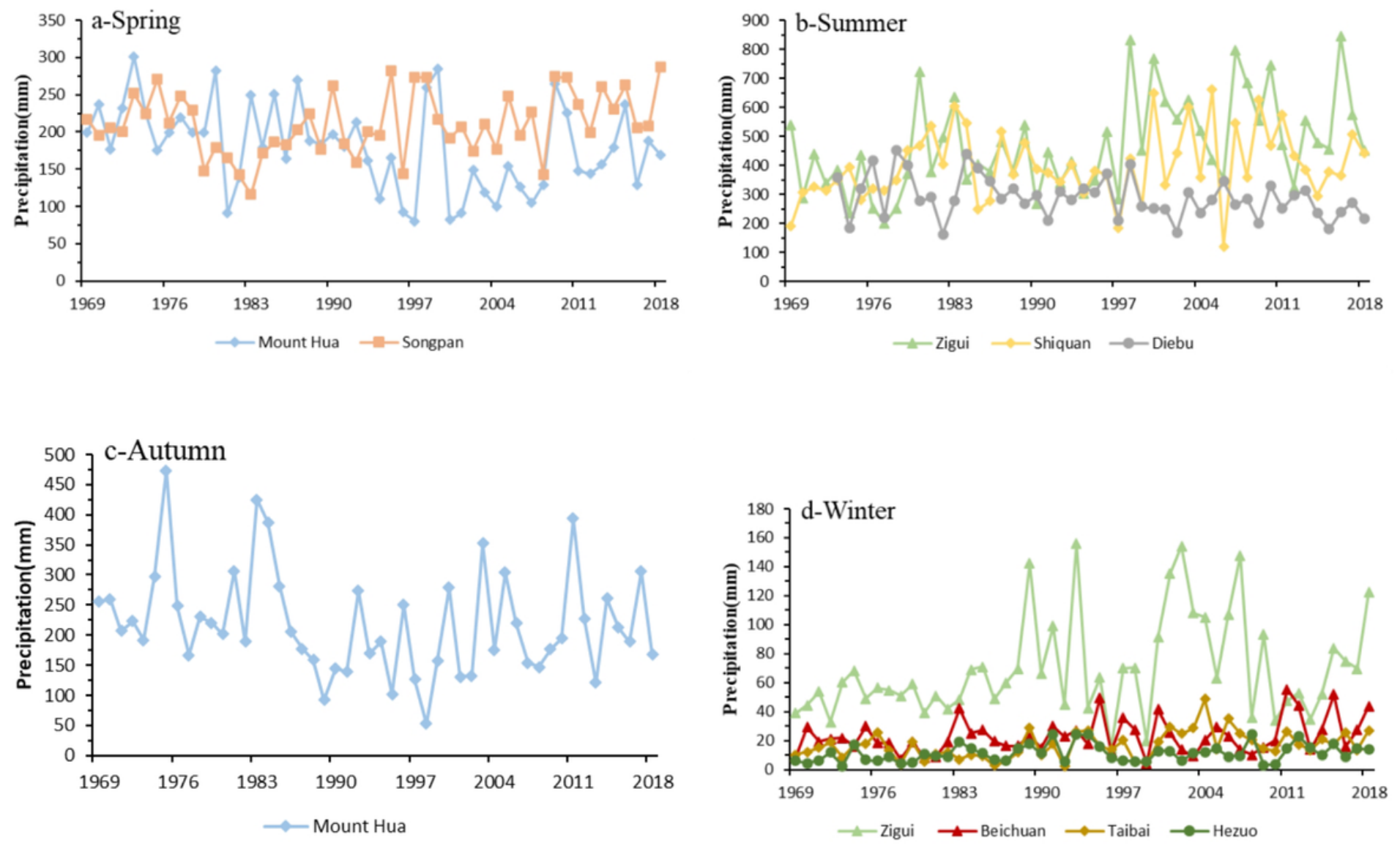

\section{Figure 7}

Precipitation changes significantly at the weather stations in different seasons in the QDM during 1969ه2018: spring(a), summer(b), autumn (c)and winter (d) 